DOI: 10.32089/WBH.PHW.2019.3(269).0009

orcid.org/0000-0001-8838-5651

\title{
The judiciary of the Polish Underground State under the investigation of a German researcher
}

Oscar Szerkus, Die Sondergerichtsbarkeit des PoInischen Untergrundstaates, Berlin 2019, 469 pages

This year the Berlin-based publishing house Duncker \& Humboldt published the 183th volume from the prestigious Schriften zur Rechtsgeschichte series on the judiciary of the Polish Underground State during World War II. It is a printed version of Oscar Szerkus's doctoral dissertation entitled Die Sondergerichtsbarkeit des Polnischen Untergrundstaates, written under the supervision of Professor Ignacio Czeghun and defended at the Free University of Berlin (Freie Universität Berlin) in 2018. Among the reviewers of the dissertation there were no Polish researchers, so it is worth taking a closer look at how our Western neighbors perceive the phenomenon of the Polish Underground State through the prism of the functioning of its legal branch, i.e. the underground jurisdiction. The reviewed book consists of an impressive introduction with preliminary considerations, two extensive subject-matter chapters, the third chapter, in which the author discussed the source documents, and an extensive appendix, which is a flagship of German scientific dissertations, in which the author included the more important - in his opinion - legislation documents, copies of underground judiciary sentences and orders concerning Polish Underground State courts. In the final parts of the book, the author included a summary and a list of bibliographical entries. Each chapter also contains a concise résumé. In the text, the author used the historical and dogmatic method interchangeably. The latter was necessary for conducting comparative legal analyses.

I shall start the review with a general remark: the author did not reach new sources and relied solely on Polish historical or historical-legal literature. Apart from individual cases, he did not refer to new source documents from German archives, which could be connected with the activity of the underground judiciary. The question is, are such documents available in German archives in the first place? Unfortunately, we do not know that. Certainly, it would be an interesting look at the judiciary of the Polish Underground State from the 
perspective of the security apparatus of the Third Reich. On the other hand, we should only be glad that the author relied on Polish historical literature. In this way, he was prevented from coming to erroneous, hasty conclusions. Recently, we have seen an abundance of home-grown historians who seek cheap applause with sensationalism, and not as researchers. In this respect, Oscar Szerkus turned out to be thorough. He also did not overlook the valuable work of Polish researchers, including the work on the German judiciary in the General Government (e.g. by Andrzej Wrzyszcz ${ }^{1}$ ). This undoubtedly proves his erudition and good knowledge of the issues of the Polish resistance movement. Szerkus acted like a seasoned researcher. He did not pretend to work with sources, but conducted a thorough review of Polish literature. The question is, what did he ground his narration on, as his work consists of several dozen publishing sheets?

The evaluation of the bibliography used in the book is definitely favorable for the author. Oscar Szerkus took into account the achievements of researchers who published over the last half-century on such issues as the system of the highest military authorities, military penal law of the 20th century, and above all on the history of the Polish military in the years 1939-1945. He did not omit memoir literature either, which is extremely rich. I am pleased with the fact that Władysław Sieroszewski's typescript about the Military Special Courts in Warsaw was reached, for which the author thanked Bartłomiej Szyprowski. In the bibliography we come across researchers of the history of military law, the activity of Directorate of Diversion (pol. Kierownictwo Dywersji, Kedyw ${ }^{2}$ ) and the underground judiciary. However, there are also works very distant from the issues related to the organization and functioning of the Polish Underground State, out of which I shall point to, among others, Anna Stawarska-Rippel's publication on the impact of the codification of Russian civil procedure on the work of the civil procedure section of the Codification Commission of the Second Polish Republic ${ }^{3}$, Marek Chmaj's monograph on the Polish Parliament of the $1990 \mathrm{~s}^{4}$ or Józef Wójcicki's monograph on the history of the Free City of Danzig in 1920-19395. The author also drew on the achievements of em-

A. Wrzyszcz, Okupacyjne sadownictwo niemieckie w Generalnym Gubernatorstwie 193945: organizacja i funkcjonowanie, Lublin 2008.

2 Directorate of Diversion of the Home Army Headquarters (pol. Kierownictwo Dywersji Komendy Głównej Armii Krajowej) - organ of the Polish Home Army specialized in the sabotage and liquiditionary actions against german ocupational forces, german officials especialy most „deserving” war criminals - and collaboratiors.

A. Stawarska-Rippel, Rosyjska procedura cywilna w pracach sekcji postepowania cywilnego Komisji Kodyfikacyjnej II RP na przykładzie projektu „Tytułu o dowodach” J. J. Litauera, "Z Dziejów Prawa” 2010, pp. 79-91.

4 M. Chmaj, Sejm Rzeczypospolitej Polskiej w latach 1991-1997 (I i II kadencja): studium prawnoustrojowe, Warszawa 1999.

5 J. Wójcicki, Wolne Miasto Gdańsk 1920-1939, Warszawa 1976. 
igrant researchers and does not distinguish between works from the distant times of the Polish People's Republic and those published recently. Unexpectedly and without a just reason, the grim figure of Julian Polan-Haraschin, a Stalinist court murderer who contributed to the history of the communist judiciary in the years of the Gomułka thaw, appears on the pages of the book ${ }^{6}$. If the author wanted to demonstrate his knowledge of Polish criminal law of the last century, he should rather reach for the works of major researchers of the history of legal sciences. Personally, I missed the valuable monographs by Adam Lityński $^{7}$ and Tomasz Szczygiel, especially that the latter shared the results of his research on the codification of the criminal procedure of the Second Polish Republic two years ago. The aforementioned book took into account, among others, the development of military court law in the Second Polish Republic ${ }^{8}$. I also missed the interesting monograph by Janusz Marszalec on the activities of the military judiciary in the Warsaw Uprising, although the author used his other valuable publications ${ }^{9}$. However, the accusation of omitting one or another item from the bibliography is always easy for the reviewer. Such accusations may concern the luminaries of humanities and authors of the most interesting monographs. Meanwhile, Oscar Szerkus defends himself with the diversity of the literature used. In view of its abundance, he was certainly forced to make a careful selection. As the reviewer, I had an impression that the author focused on the works of certain researchers (e.g. Bartłomiej Szyprowski, Piotr Szopa), and these have been published recently and have been well received ${ }^{10}$. The bibliography is supplemented by printed collections of source documents concerning the organization and activity of the Polish Underground State in 1939-1945 in national and emigration editions. As luck would have it, Oscar Szerkus was late for the "revelations" of Wojciech Lada, the title of which I shall not quote out of courtesy to the memory of the Home Army11 (pol. Armia Krajowa, AK)

$6 \quad$ J. Haraschin, Zarys dziejów Wojskowej Stużby Sprawiedliwości w Polsce w latach 19181958, „Wojskowy Przegląd Historyczny” 1959, No. 4, pp. 181-220.

7 A. Lityński, Historia prawa Polski Ludowej, Warszawa 2005.

8 T. Szczygieł, Unifikacja i kodyfikacja wojskowej procedury karnej w II Rzeczypospolitej, „Czasopismo Prawno Historyczne" 2017, No. 1; idem, Wojskowe postępowanie karne w II Rzeczypospolitej (1918-1939), Katowice 2017; idem, Wojskowe postępowanie polowe i doraźne w II Rzeczypospolitej, „Z Dziejów Prawa” 2016, vol. 9 (17) pp. 59-81.

9 J. Marszalec, Ochrona porządku i bezpieczeństwa publicznego w Powstaniu Warszawskim, Warszawa 1999.

10 See B. Szyprowski, Sąd Kapturowy przy Komendzie Głównej Związku Walki Zbrojnej (sierpień 1940 r. - listopad 1941 r.), Warszawa 2016; P. Szopa, W imieniu Rzeczypospolitej... Wymiar sprawiedliwości Polskiego Państwa Podziemnego na terenie Podokręu AK Rzeszów, Rzeszów 2014.

11 Home Army (pol. Armia Krajowa, AK) - formed in 1942 on the basis of the Union of Armed Struggle was a part of the Polish Armed Froces of the legitimate Polish Government in Exile. It main objectives was coordinatnion, prepartion and execution of diversive, 
soldiers and the historical truth. Fortunately, the German researcher is tactful and serious, so I do not believe that he would like to use such tabloid literature anyway. In his book, the author showed a lot of empathy for our occupation times, for which I am grateful.

Referring to the substantive content of Oscar Szerkus's book, I shall risk the statement that the young German researcher reproduced the findings of Polish historians and did not surprise us in any particular way. This does not mean, however, that he went the easy way and compiled a book from the works of Polish authors. The author came to all the findings and conclusions by himself, which we can trace by following his narration in detail. The author meticulously recreated the state of Polish affairs during World War II. He reconstructed the course of the Polish campaign of 1939, the activity of the Chief Civil Commissioner in the fighting capital, recalled the beautiful figures of Stefan Starzyński and General Walerian Czuma, thoroughly discussed the origins of the establishment of the Service for Poland's Victory (pol. Służba Zwycięstwu Polski, $\left.\mathrm{SZP}^{12}\right)$, the transformation of this organization into the Union of Armed Struggle (pol. Związek Walki Zbrojnej, ZWZ) ${ }^{13}$, the personal drama of Marshall Edward Śmigły-Rydz, and taking over the constitutional powers by General Władysław Sikorski and his political camp in exile. Szerkus also reconstructed the process of the concentration of full political and military power in exile in the hands of the new Commander-in-Chief. The author presented the consolidation process of non-communist organizations and underground groups, the creation - as he notices - of the Home Army of ca. 390000 soldiers, the prolonged crystallization of the legal framework of the Polish Underground State, to certain executions and elimination operations of the Kedyw. In one word, the German reader was acquainted with the epic story of Warsaw's defense in September 1939, including the first decisions of Marshall ŚmigłyRydz about the creation of the initial conspiracy, and even with a broad reference to the tradition of the Polish Military Organization during World War I. Interestingly, in his research the author put strong emphasis on determining the legal basis for the activities of the President of the Republic of Poland

propaganda and military operations on the teritories occupied by German and Soviet forces with the aim on liberating polish territories from occupation [translator's footnote].

12 Service for Poland's Victory (pol. Służba Zwycięstwu Polski) - Polish underground organisation formed on 27 September 1939 in Warsaw on the orders of gen. Juliusz Rómmel a day before Warsaw capitulation. First comander was general Michał Karaszewicz-Tokarzewski. In January 1940 reformed in the Union of the Armed Struggle [translator's footnote]..

13 Union of Armed Struggle (pol. Związek Walki Zbrojnej, ZWZ) - predecessor of the Polish Home Army, underground amred organization formed on the basis of the Service for Poland's Victory in January 1940. Directed by the Polish Government in Exile it was organisationaly divided to two parts - for the German and Soviet occupied teritories. It's main goal was the preparation of forces for the national uprising. In 1942 reformed in to the Home Army [translator's footnote].. 
and the Council of Ministers in exile, and on the legitimacy of the activities of the Union of Armed Struggle headquarters in the occupied country. Thus, we find here a professional legal and comparative analysis of constitutional law issues, references to the Constitution of the Republic of Poland of April 23 ${ }^{\text {rd }}$, 1935 and selected orders of the Commander-in-Chief from 1939-1940. The author clearly strived to clarify the legal status of the „decision-making center in exile and the executive in the occupied country" in relation to the launch of underground courts activity. Oscar Szerkus did not omit the exchange of correspondence between the Commander-in-Chief Staff in France and the command of the Union of Armed Struggle in Warsaw, which was characteristic of the first year of the occupation, concerning the scope of the underground courts activity. I also welcomed the presentation of the political and legal position of the Polish government in exile after the unexpected defeat of France, and the presentation of selected works of the Council of Ministers in London, whose aim was to define the legal framework for the activities of the Polish Underground State in the occupied country. If the author had any personal preferences towards the leading figures of Polish political and military life, he was able to refrain from making comments. These are barely visible, not to say that we could only make guesses about them. For example, when the author presented the crisis among the leaders of the Polish authorities in exile in July 1940 after the surprising defeat of France, when General Sikorski could really lose his power, the actual position of the Commander-in-Chief was summed up clearly and explicitly: ,weak leadership” („unter politisch schwacher Führung”, p. 186). At the same time, the author did not hide his appreciation for General Stefan Rowecki and the command of the Union of Armed Struggle-Home Army in the occupied country.

As a consequence of the research field chosen by Oscar Szerkus, the realities of the German occupation are presented, and in the period from October 1939 to the beginning of July 1941, also concerning the Soviet occupation. On several occasions the author stressed the need for the Polish society to undertake self-defense in the face of the unprecedented extermination of its leaders. What is also important, the author did not soften or justify the criminal character of the Nazi regime, which we sometimes encounter in the Federal Republic of Germany. Personally, I am impressed by the erudition of this young researcher and his knowledge of an apparently complex issue. The book did not lack even the profiles of prominent underground lawyers of the Home Army (e.g. Colonel Konrad Zieliński - „Karol”) and information on the structures of the underground administration operating within the framework of the Government Delegation for Poland. Even in Poland we have a limited number of researchers who deal with this issue (Waldemar Grabowski, Grzegorz Górski, and others). In the last part of his extensive book, Oscar Szerkus presented selected criminal trials from the case lists of the Military Special Courts of Polish Union of Armed Struggle and Home Army, and to a lesser extent also of 
the Civil Special Courts. The entire text features numerous footnotes, which refer to the works of Polish researchers and preserved source documents. The book ends with reprints of legal acts, statutes of the Military Special Courts (pol. Wojskowe Sądy Specjalne, WSS), and sentences of underground courts. And despite the fact that we will not find any novelties here, the book makes a good impression as a whole. A noticeable shortcoming of the reviewed book is insufficient proofreading, which manifests itself in numerous spelling errors in the titles of Polish publications in many footnotes. It is a pity that the author of such a laborious book decided to make an imitation of an index of names. A full index of names would have been very helpful to the reader.

Moving on to specific remarks, if something really caught my attention in this work, it was the scale in which Polish military activity was presented in view of the exodus of the highest military authorities after the September defeat and their role in the creation of organized underground structures in the occupied country. The German reader gains basic, yet delivered in a professional manner, knowledge on the establishment of Polish Underground State structures, on the exchange of views between the Commander-in-Chief's Staff in exile and the command of ZWZ-AK in the occupied country, on the course of work on criminal law sources for underground courts and on determining their area of competence. Oscar Szerkus devoted the lion's share of his work to this issue, even to the detriment of the review of the activities of the underground courts and the elimination operations carried out. This is where I see a fundamental difference in the approach to the research question between the young German historian and a large number of Polish authors. None of us, writing about the activity of the Military Special Courts, the epic story of Kedyw, spectacular elimination operations and military penal law in the years of World War II, addressed so meticulously the issue of legal empowerment of the ZWZ-AK headquarters, and the Government Delegation for Poland to initiate underground judicial activity. From our point of view, this is obvious. Appalled by the inhumanity of both occupants, we do not conduct in our works in-depth legal analyses of the legality of underground court sentences. Usually we also do not discuss the compliance of sentences of the underground judiciary with military law, although Bartłomiej Szyprowski did so in his last book about the so called „sądy kapturowe" 14 at the ZWZ headquarters in the first stage of the war $^{15}$. Doubts usually concern individual sentences, where a few specialists and

14 The literally translation would be "hooded courts” - extraordinary court system estabilished in 1940 by the Committee of Ministers for Affairs in the Country for military and civilian branches and approved by Commander-in-Chief. Later replaced by the WSS. This courts name and procedure alluded to the long tradition of such courts in the history of Poland and Polish-Lithuanian Commonwealth [translator's footnote].

15 Zob. B. Szyprowski, Sad Kapturowy..., pp. 48-53. 
hobbyists discuss whether the death sentences issued by the WSS and Home Army military field courts against the journalist Czesław Ancerewicz, poet Teodor Bujnicki, Lieutenant Colonel Emil Macieliński, Lieutenant Józef Świda „Lech”, etc. were justified. Meanwhile, Oskar Szerkus does not go into individual cases and does not question the legality of these sentences. Instead, he broadly considers the issues of the evolution of military criminal law and broadly refers to the sources of Polish judicial law. This is where I shall allow myself to digress.

In the second chapter, the author went for a detailed analysis of the sources of Polish public and military criminal law, starting from the second decade of the interwar period. In my opinion, this was completely unnecessary for the examination of the legal basis of the underground judicial activity during World War II. The WSS adhered to the provisions of the Statute, and when necessary to the provisions of the military penal code of 1932 and the regulations on ad hoc proceedings. Oskar Szerkus also highlighted the rules of the penal procedure from the late 1920s, which also did not have a wider application in war jurisdiction. Let us remember that the WSS acted in line with abridged court procedures, which did not take into account the procedural guarantees of the defendants. We will not find in these procedures any protection of the principle of directness or other achievements of the Enlightenment era of this kind. The realities of war forced underground lawyers to go back two centuries. The defendants were not brought before the judges, they were not presented with charges, their defense was not accepted. This can only be found in war films. In one word, the audiatur et altera pars principle did not apply in underground courts, expect for extraordinary situations or at field court trials. If a WSS referred to military penal procedure, it would first of all refer to the code of military penal procedure of 1936. Oscar Szerkus proved in this book that he knew the issues of the sources of military penal procedure. When the author analyses the evolution of Polish criminal law, he should notice that the majority of legal and criminal institutions in interwar Poland were taken over expressis verbis from the public and military criminal law of the Second German Reich, which was codified in 1871-1872. Let us remember that as early as in 1917 the Legal and Military Commission of the Provisional Council of State of the Kingdom of Poland, acting on the order of Józef Piłsudski under the supervision of MajorAuditor Alfred Ganczarski, deliberately chose German criminal legislation as the best of all the partition regulations. Is it worth to spend time for detailed analyses of Polish legal and penal institutions in the interwar period, which were mostly of German origin? After all, we adopted German criminal law as the best source of judicial law, which is not surprising at all, as medieval German municipal law was the basis for the organization of Polish towns and the source of town acts from the middle of the 13th century onwards. Nevertheless, the author must be given credit for the fact that he has demonstrated comprehensive knowledge of Polish judicial law. Beyond doubt, this is visible in the 
author's arguments on pages 267-277, where he summarized the evolution and the most important stage of work on the law of war of the underground judiciary. It also has to be acknowledged that he thoroughly tackled the issue of the creation and legal bases for the functioning of the Civil Special Courts (pol. cywilne sądy specjalne, CSS) subordinate to the Regional Government Delegates for Poland. Few Polish researchers, including the undersigned, dealt with the activity of the CSS as deeply as Oskar Szerkus did. Civil Special Courts did not make any spectacular judicial decisions like the Military Special Courts, and researchers are reluctant to refer to their judgements, especially that the source material concerning the activity of the CSS is incomplete, not to say that only remnants have been preserved. The so-called delegate courts, as we popularly call them in literature, were composed of pre-war advocates. They in turn had a lot of understanding for the defendants, which was reflected in the gentleness of the sentences.

The second remark is of practical value. The author traced the authority of the highest political and military powers of the Second Polish Republic to establish war law back to the Constitution of 23 April 1935 and quoted the full text of the constitution in annexes (pages 404-418). Personally, I do not consider this the right thing to do, as it would make more sense to quote fragments of three normative acts from 1 September 1939, which defined the legislative and judicial competences of the highest Polish authorities. These are the fundamental sources for our deliberations, so I will quote their full titles, as the author missed them in the annexes: 1) Decree of the President of Poland from 1 September 1939 „On the exercise of authority over the Armed Forces, on the organization of the supreme military authorities and on civil commissioners from the moment of appointment by the Supreme Commander"16 2) Order of the President of Poland from 1 September 1939 „On martial law”17 3) Regulation of the Council of Ministers from 1 September 1939 „On the introduction of special proceedings in common courts in cases concerning certain crimes" ${ }^{\prime \prime}$. Only the Ordinance of the Council of Ministers from 1 September 1939 „On the state of emergency"19 could be omitted, as it consisted of one sentence. However, the above-mentioned three legal acts should have been highlighted by the

16 Dekret Prezydenta Rzeczypospolitej z 1 września 1939 r. o sprawowaniu zwierzchnictwa nad Siłami Zbrojnymi, o organizacji naczelnych władz wojskowych i o komisarzach cywilnych - od chwili mianowania Naczelnego Wodza (Dz. U. RP z 1939 r., nr 86, poz. 543) 17 Zarządzenie Prezydenta Rzeczypospolitej z 1 września 1939 r. o stanie wojennym (Dz. U. RP z 1939 r., nr 86, poz. 544).

18 Rozporządzenie Rady Ministrów z 1 września 1939 r. o wprowadzeniu postępowania doraźnego przed sądami powszechnymi w sprawach o niektóre przestępstwa (Dz. U. RP z 1939 r., nr 87, poz. 554).

19 Zarządzenie Rady Ministrów z 1 września 1939 r. o stanie wyjątkowym (Dz. U. RP z 1939 r., nr 85, poz. 542). 
author, because ad hoc law was applied by some WSS during the war, and the application of ad hoc law had a long tradition in the Second Polish Republic. I shall mention here the years of the fight for Poland's borders (1918-1922) or the 1934 subjection of some dangerous crimes against state security. Andrzej Krzysztof Kunert, Paweł Maria Lisiewicz, Bartłomiej Szyprowski, Leszek Gondek, the undersigned and other authors have written about it. The young German researcher's discussion on the legal, purely formal side of the underground courts' activities may irritate the Polish reader. Let us remember, however, that this book is not intended for my countrymen. Oscar Szerkus consistently raises the question of the legal basis for the underground judiciary activities. Putting emotions aside, however, we can see that this is a serious research problem. If compared with the mass murder committed on Polish soil by the occupants, the question of the legality of WSS and CSS judgments appears to be of purely academic character. Today we know that Home Army district level commanders carried out the elimination operations of renegades without WSS sentences. These were mass elimination operations ordained on the basis of requests of Home Army district security clerks. However, I understand the pure intentions of foreign researchers who want to put the functioning of the Polish Underground State, including the justice service, into a formalised framework. And legal norms are the most useful in this case.

The next remark concerns the discussion of the relations between the President of Poland and the Commander-in-Chief and has a strictly political context. If Oskar Szerkus followed the dogmatic narrative and looked so deeply for the origins of legal and penal institutions, he should not have omitted an issue of fundamental nature. Out of the three normative acts which I quoted above and which should have been included as annexes in fragments or as a whole, the presidential decree was the most important from the point of view of the judicial activity of war courts. According to Article 3 of the decree, the President exercised authority over the Armed Forces through the Commander-in-Chief or the Minister of Military Affairs. According to Article 7-9 of the Decree, the Commander-in-Chief was given general supervision in matters related to ensuring the security of the Armed Forces. It was the Commander-in-Chief who was politically accountable to the President of Poland for the introduction of special proceedings in the operational area. This privilege was of a special nature, as under the provisions of the act on military judiciary (Article $46 \$ 2$ ) and the code of military criminal procedure (Article $553 \$ 2$ ) this power could not be exercised by another entity unless the Commander-in-Chief delegated these powers to them. Only the Commander-in-Chief could give orders to military special courts and such a practice had already taken place during the war with Soviet Russia (1919-1921) or with Ukrainians for Eastern Galicia (1918-1919). Such legal basis gained even more importance when General Władysław Sikorski, after the September defeat in France, simultaneously obtained the powers 
of the Commander-in-Chief, the Prime Minister and the Minister of Military Affairs. The reason for this remark being so important for the discussions in the reviewed book is that until the crash in Gibraltar, the Commander-in-Chief's Staff was infected with vengeful madness for the post-May regime cadre. I shall only recall, for example, the sensitive issue of the deceitful transfer of General Stefan Dąb-Biernacki from the internment in Hungary to France in order to present him with criminal charges or the concentration camps for Piłsudski's followers in Cerizay and on the Isle of Bute. Among those loyal to Sikorski, the issue of the selection of judges in the underground judiciary was controversial. The Chief Commander's Staff feared that underground courts in the occupied Poland would fall into the hands of the Sanation officers. This actually happened to some extent and nothing terrible happened to the independence cause. The administration of the justice service of the Home Army Headquarters was entrusted to Colonel of the reserves Witold Stefan Szulborski „Mora” and Colonel of the reserves Konrad Zieliński „Karol”, merited pre-war auditors. The first one made outstanding contributions to the creation of the judiciary in the years of the wars for Poland's borders and organized the field court of the „Warsaw” Army in September 1939, and the second one was always associated with the Sanation ${ }^{20}$ camp. After the war, he was put through horror in the casemates of the Ministry of Public Security. Meanwhile, most of the judges, including the heads of the justice service of the District Commands of the Union of Armed Struggle and Home Army, came from among the advocates or from the common justice system. This was the rule behind personal selection to the WSSs, because the Gestapo selected former auditors as potential judges in the underground judiciary. The use of pre-war auditors in the conspiratorial judiciary was therefore risky. London's concern for the WSS staffing and pettiness in personnel policy does not give the best testimony to the supporters of General Sikorski and probably to himself. It is also another proof of the so called „Polish Hell"21. It is all the more painful that this took place in a time of biological annihilation of the whole nation. Oskar Szerkus did not write about it, as he consistently avoided sensitive and difficult issues in his book. Incidentally, one day I would like to see a text a few publishing sheets long featuring a German researcher's discussion on the legality of the drumhead court-martials, the socalled Standgericht, established by General Walther von Brauschitsch's order from 12 September 1939. During the occupation of Poland, these courts issued

\footnotetext{
20 See biograms of these officers in: L. Kania, Wyroki bez apelacji. Sady polowe Wojska Polskiego $w$ czasie wojny $z$ Rosją Sowiecka 1919-1921, Zielona Góra 2019. Biograms of mentioned can be found in many other works for exaple: biographical dictionary of the Polish attorneys (w słowniku biograficznym adwokatów polskich) (ed. 2008), monographs and dictionaries by B. Szyprowski, J. Skelnik i A. K. Kunert.
}

${ }^{21}$ Polish phrase „polskie piekiełko”. 
several thousand death sentences on former Silesian and Greater Poland insurgents, „Rodło” activists, scouts, and others.

The last point concerns a fundamental issue, albeit as painful as the observations made above. While it is difficult to criticise Oskar Szerkus for what he has written, although this should actually only please us, we must refer to what he has not included in his book. The author omitted perhaps the most sensitive issue of all that concerns the underground judiciary. It is about the answer to this question: did the Commander-in-Chief Staff in Angers, and then in London, where the real political-military authority in exile was concentrated, ever want to start an underground system of justice in the occupied country? Oscar Szerkus barely mentioned it, but this issue is still controversial today. This is because the path to developing underground judicial structures in the occupied country was long and bumpy. It is hard to say why, but the decision-making center in exile as late as six months after the September defeat claimed that in order to ensure the safety of the Service for Poland's Victory, and then the Union of Armed Struggle, one court located by the Commander-in-Chief of the organization would suffice. Colonel Stefan Rowecki - „Rakoń” considered such a conception to be completely wrong, justifying it with the scale of extermination of the Polish intelligentsia and leaders, and the need for a quick reaction against provocateurs and collaborators ${ }^{22}$. After the elimination of Igo Sym in March 1941, a well-known actor and at the same time a dangerous Gestapo informer, the Staff of the Commander-in-Chief accepted this sentence and the execution with great reserve, because the Germans in retaliation shot 21 Poles. London, however, did not manage to stop the development of the underground judiciary structures, but for more than a year and a half tried to minimize the activity of the Union of Armed Struggle-Home Army WSS and make them subordinate to the Government Delegate for Poland. Eventually, after two years (!), the principles of organizing the Polish Underground State justice service were finally worked out ${ }^{23}$. If it had to exist, it was only to a limited extent and only in justified cases of self-defense. Even a cursory analysis of the source documents allows us to accept the thesis that London was afraid of the development of underground courts under the auspices of the Sanation-influenced administration of this service. Today, it is difficult to consider such reasoning to be correct. Unfortunately, however, this was the case. A researcher from the Netherlands, Finland, Belgium or Brazil would have no problem showing this twisted Polish puzzle, which we regularly treat ourselves with in every century.

22 J. Paśnik, Problematyka podziemnego sądownictwa wojskowego $w$ korespondencji Komendanta Głównego ZWZ / AK z rządem emigracyjnym, „Czasopismo Prawno-Historyczne” 1987, No. 1, p. 187 and n.; Armia Krajowa w dokumentach 1939-1945, Londyn 1970, vol. 1, p. 152.

23 See L. Kania, Stużba sprawiedliwości w Wojsku Polskim 1795-1945. Organizacja - Prawo - Ludzie, Siedlce 2015, pp. 408-418. 
Oscar Szerkus was obviously constricted as a German researcher, so in the book we can see his sensitivity to the difficult Polish issues.

To sum up, the reviewed work of Oscar Szerkus is a legal-historical book. It is a comprehensive, concisely presented text intended for a narrow circle of specialists in the fields of military history and the history of law. This automatically implies that it is not going to be a satisfactory read for the mass reader. But it is a scientific work of the highest quality, which according to Polish criteria meets the requirements for a habilitation dissertation thanks to its scale, depth of research and use of sources. Let us remind once again that this is a printed version of a doctoral dissertation. In the author's intention, the reviewed book, to put it euphemistically, is addressed to a more sophisticated audience. And this goal is fulfilled. We will not find cheap gimmicks here, nor descriptions of elimination operations and reports from field court trials. What is important, the author does not violate in the slightest degree our sensitivity to the fundamental issues. Although it touches upon various faces of collaboration, which is fully understandable, it does not exceed the limits of historical truth. Therefore, there is no trace of a new interpretation of the past on the pages of this book. We are doing far more harm to ourselves in this regard on our own. The author presents the reader with a tragic chapter of the recent Polish history through the prism of the occupation reality. That is why Oscar Szerkus's book is a guide for the German audience to the history of the Polish resistance in 1939-1945, in which the underground judiciary serves only as a good starting point to learn about the phenomenon of the Polish Underground State in the years of World War II. It is also a comprehensive look at the Polish military effort in this war. And that already required an exceptional erudition, which Oscar Szerkus impressed me with.

Leszek Kania 